\title{
Infection with human immunodeficiency virus (HIV) and cytomegalovirus in a London health district $1980-4$
}

\author{
M G R ROSS,* D MacDONALD BURNS, $\uparrow$ J E GRUNDY,* AND P D GRIFFITHS* \\ From the *Virology Unit and the $†$ Marlborough Department of Sexually Transmitted Diseases, The Royal \\ Free Hospital and School of Medicine, London
}

SUMMARY By testing serum samples taken between 1980 and 1984 from men attending a department of sexually transmitted diseases, it was shown that antibodies to human immunodeficiency virus (HIV) first appeared in 1981. Homosexual men were significantly more likely to have antibodies to HIV and to cytomegalovirus (CMV) than were heterosexual men attending the same clinic. This shows that homosexuals are exposed to both HIV, the cause of the acquired immune deficiency syndrome (AIDS), and to CMV, which can reactivate to cause life threatening disease once immunosuppression has developed. All homosexuals, not just those with antibodies against HIV, had raised levels of CMV antibodies. This suggests that they experience frequent antigenic stimulation after reinfections with CMV or reactivation of endogenous virus.

\section{Introduction}

It is now generally accepted that the acquired immune deficiency syndrome (AIDS) is caused by infection with human immunodeficiency virus (HIV), previously known as human $\mathrm{T}$ cell lymphotropic virus type III (HTLV-III), ${ }^{1-6}$ or lymphadenopathy associated virus ${ }^{1}$ or AIDS related virus. ${ }^{7}$

The first case of AIDS in the United Kingdom was reported at the end of $1981 .{ }^{8}$ As the disease has a long incubation period, this suggests that the virus was being transmitted before that year. To identify when infection with HIV first appeared in our health district, we tested serum samples stored for five years, which had been collected from men attending the sexually transmitted diseases (STD) department. In addition, we tested these serum samples for antibodies against cytomegalvirus (CMV), which is a common opportunistic pathogen in patients with AIDS.

\section{Materials and methods}

\section{SERUM SAMPLES TESTED}

All serum samples submitted from the STD department since 1980 had been stored at $-20^{\circ} \mathrm{C}$. Those taken from men aged 15-45 years were retrieved and

Address for reprints: Dr P D Griffiths, Virology Unit, The Royal Free Hospital, Pond Street, Hampstead, London NW3 2QG

Accepted for publication 25 May 1986 tested for antibodies against HIV and CMV. These serum samples had been collected for diagnostic purposes, which in most cases related to the possibility of infection with genital herpes simplex.

\section{SEROLOGICAL METHODS USED}

FOR HIV

Antibodies against HIV were measured by the "HTLV-III bio-enzabead test" (Ortho Diagnostic Systems/Litton-Bionetics). The manufacturer's instructions were briefly as follows. Each serum sample was diluted $1 / 75$ in dilution buffer. A metallic bead coated with virus antigen was then added and incubated at $37^{\circ} \mathrm{C}$ for 90 minutes. The metallic bead was washed with wash solution and immediately transferred to optimally diluted peroxidase conjugated goat anti-human immunoglobulin. The bead was incubated at $37^{\circ} \mathrm{C}$ for 30 minutes then washed again in fresh wash solution. Finally the bead was transferred to the substrate solution for 10 minutes at room temperature. The reaction was stopped with sodium fluoride, and the absorbance of the green coloured product was measured using a microplate spectrophotometer (Flow, Irvine) at a wavelength of either $410 \mathrm{~nm}$ or $690 \mathrm{~nm}, 690 \mathrm{~nm}$ being used throughout the present study. The cut off point was calculated from the mean of the negative control serum samples plus a constant absorbance value of $0 \cdot 11$. All 28 
point were recorded as being reactive.

Serum samples giving positive reactions were tested by another commercially available assay (Wellcozyme; Wellcome Diagnositics). Briefly, $25 \mu \mathrm{l}$ of each serum was added to microwells containing immobilised HIV antigen. Human antibody to HIV conjugated to horseradish peroxidase at a working dilution $(75 \mu \mathrm{l})$ was added to each well and incubated at $45^{\circ} \mathrm{C}$ for one hour, the wells were washed, and $100 \mu \mathrm{l}$ of substrate solution was added and incubated for 20 minutes at room temperature. The reaction was stopped with sulphuric acid, and the yellow coloured product was measured spectrophotometrically at $450 \mathrm{~nm}$. The cut off point was calculated from the mean given by the control serum, and serum samples with lower absorbance values were considered to contain antibody to HIV.

FOR CMV

Antibodies against CMV were measured by solidphase radioimmunoassay as described previously in detail elsewhere. ${ }^{9}$ The quantity of IgG antibody specific to CMV was expressed as the binding ratio at a serum dilution of $1 / 100$ - that is, the amount of radioactivity bound at this dilution divided by that of the background.

\section{STATISTICAL METHODS}

The significance of differences between distributions was assessed by the $\chi^{2}$ test or, when appropriate, Fisher's exact test. The difference between mean values was assessed by a two tailed $t$ test.

\section{Results}

A total of 430 serum samples from men aged 15 to 45 attending the STD department were tested, and of these $11(2.6 \%)$ gave positive results for HIV antibodies when tested with the Ortho assay. Ten of these serum samples were also positive when tested by the Wellcome assay. The remaining sample was repeatedly positive by the first assay but repeatedly negative by the second. This sample had been collected in 1981 from a heterosexual man with no risk factors for HIV infection and, in view of the discrepant results obtained, was assumed to be negative for HIV antibody in the following analyses.

Table I shows the results according to the year in which the samples were collected. Evidence of infection with HIV was not found in 1980 but was found in every subsequent year.

TABLE I Appearance of seropositivity to human immunodeficiency virus (HIV) in 1981 and seropositivity to cytomegalovirus (CMV) in men attending sexually transmitted diseases clinic

\begin{tabular}{lrlr}
\hline & & \multicolumn{2}{l}{$\begin{array}{l}\text { No (\%) of men with } \\
\text { antibodies against: }\end{array}$} \\
\cline { 3 - 4 } $\begin{array}{l}\text { Year } \\
\text { serum } \\
\text { taken }\end{array}$ & $\begin{array}{l}\text { No of serum } \\
\text { samples tested }\end{array}$ & HIV & \multicolumn{1}{c}{ CMV } \\
\hline 1980 & 126 & $0(0)$ & $71(56)$ \\
1981 & 52 & $2(4)$ & $20(38)$ \\
1982 & 94 & $2(2)$ & $44(47)$ \\
1983 & 102 & $5(5)$ & $55(54)$ \\
1984 & 56 & $1(2)$ & $26(46)$ \\
Total & 430 & $10(2)$ & $216(50)$ \\
\hline
\end{tabular}

The 430 serum samples were also tested for antibodies to CMV, and $216(50 \%)$ were shown to be seropositive (see table I). When analysed according to year of collection, CMV antibodies were found in 1980 with no trend towards increasing prevalence in subsequent years. When the prevalence of CMV antibodies was analysed according to sexual orientation, however, it was clearly shown (table II) that significantly $(p<0.001)$ more homosexuals $(75 / 94$; $80 \%)$ than heterosexuals $(141 / 336 ; 42 \%)$ were seropositive. As expected, the possession of antibodies against HIV was also significantly $(p<0.001)$ associated with homosexuality (see table II).

The figure shows that when the reactivity of antibodies to CMV in these 216 serum samples was measured according to sexual orientation, homosexuals had significantly $(p<0.001)$ higher concentrations (mean binding ratio $=18 \cdot 3$ ) than heterosexuals (mean binding ratio $=13$ ). Homosexuals who were HIV antibody positive had similar amounts of antibody to CMV (mean binding ratio $=15.9$ ) to those who were HIV antibody negative (figure). Only one HIV antibody positive patient lacked antibodies to CMV.

TABLE II Association between sexual orientation and seropositivity to human immunodeficiency virus (HIV) and cytomegalovirus (CMV)

\begin{tabular}{|c|c|c|c|c|c|c|}
\hline \multirow{2}{*}{$\begin{array}{l}\text { Sexual } \\
\text { orientation }\end{array}$} & \multicolumn{3}{|c|}{ HIV antibody: } & \multicolumn{3}{|c|}{ CMV antibody: } \\
\hline & Positive & Negative & Total & Positive & Negative & Total \\
\hline $\begin{array}{l}\text { Homosexual } \\
\text { Heterosexual }\end{array}$ & $\begin{array}{r}10 \\
0\end{array}$ & $\begin{array}{r}84 \\
336\end{array}$ & $\begin{array}{r}94 \\
336\end{array}$ & $\begin{array}{r}75 \\
141\end{array}$ & $\begin{array}{r}19 \\
195\end{array}$ & $\begin{array}{r}94 \\
336\end{array}$ \\
\hline Totals & 10 & 420 & 430 & 216 & 214 & 430 \\
\hline
\end{tabular}




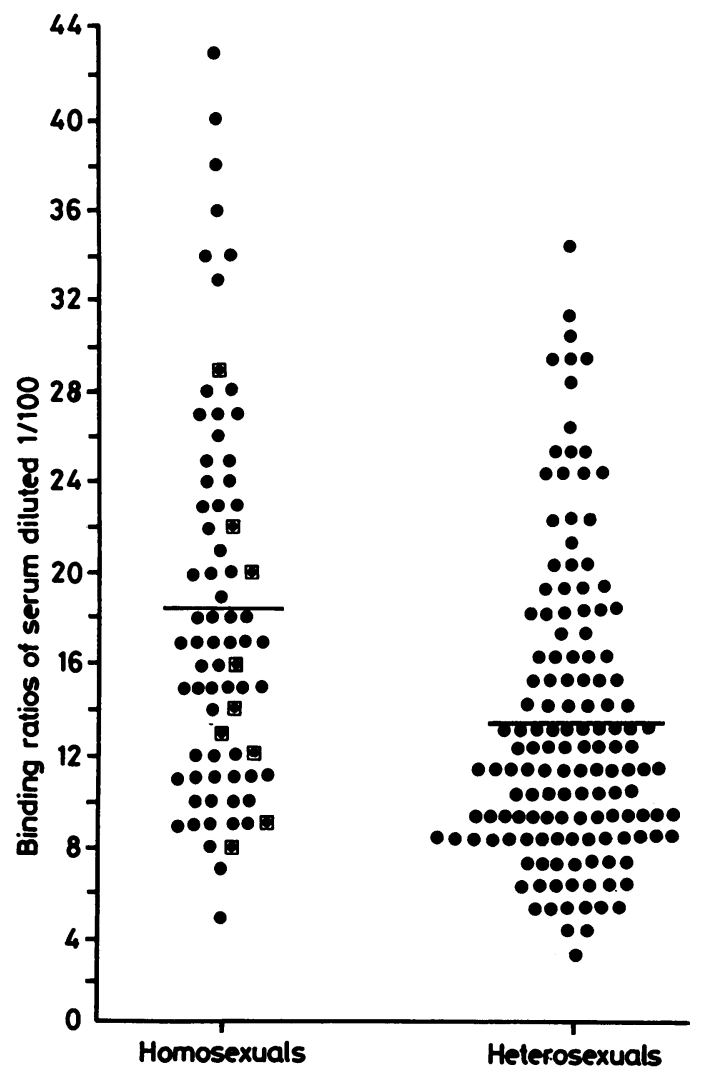

FIGURE Concentrations of antibody against cytomegalovirus (CMV) in 216 serum samples from homosexual and heterosexual men attending a sexually transmitted diseases clinic. Bars indicate mean binding ratios. Enclosed dots represent men also positive for antibody to human immunodeficiency virus (HIV).

\section{Discussion}

The results presented here show that patients infected with HIV have been attending this hospital since at least 1981. This timing of the arrival of infection with HIV is compatible with the first case of AIDS in the United Kingdom reported in December 1981.8 This correlation between the appearance of a new virus and the subsequent development of a new disease provides further support for the belief that infection with HIV is the cause of AIDS. Though Koch's third postulate has not been fulfilled by giving HIV experimentally to volunteers and showing that they develop AIDS, there is overwhelming circumstantial evidence in favour of a causal relation. $.^{1-7} 10-13$

The overall prevalence of antibodies to HIV in homosexual men $(10 / 94 ; 11 \%)$ agrees with that previously reported in a larger series from a neighbouring health district ${ }^{12}$ and from other parts of London. ${ }^{14} 15$
This relatively high prevalence should not be taken as representative of all homosexual men, as STD clinics obviously see patients whose lifestyle exposes them to STD in general. The data do show, however, that infection with HIV has spread rapidly among sexually active homosexual men attending STD clinics in London.

It was interesting to note that infection with CMV was significantly more common in homosexual than heterosexual men, which confirms a report from San Francisco. ${ }^{16}$ Thus the lifestyle of homosexuals attending STD departments exposes them to both HIV, which can cause AIDS, and to CMV, which is an important opportunistic pathogen in patients with AIDS. Furthermore, concentrations of IgG antibodies specific to CMV were significantly greater in seropositive homosexuals than seropositive heterosexuals, which suggests that the seropositive homosexuals had experienced greater antigenic stimulation with this virus. Such antigenic stimulation could result from exogenous reinfection with $\mathrm{CMV}$ or from reactivation of endogenous virus. If reactivation is more common in homosexuals than heterosexuals, the fact that the higher concentrations of antibody to CMV were not restricted to men positive for HIV is interesting. It is therefore tempting to speculate that homosexuals as a group may have impaired $\mathrm{T}$ cell immune surveillance that may permit latent viruses, such as CMV, to reactivate. This hypothesis is speculative, but lends support to the concept that the cell mediated immune functions of many male homosexuals, ${ }^{17}$ not just those who have been infected with HIV, are aberrant. The hypothesis is also compatible with the concept that HIV is itself an opportunistic agent that has spread through the male homosexual population because of an underlying immune deficiency.

Finally, our finding of evidence of infection in serum samples collected as long ago as 1981 supports our long standing decision to regard all serum samples submitted to the laboratory as being potentially infectious. All samples are handled with care, not just the minority bearing some form of "biohazard" label. We believe that training staff to practise routinely simple precautionary steps is sufficient to protect ourselves against infection with HIV or hepatitis B, and we await with interest the final report of the Advisory Committee on Dangerous Pathogens, which should contain formal recommendations for the handling of such specimens.

We thank the Society for General Microbiology for financial support, Ortho Diagnostic Systems Ltd for donating the HIV assay kits, and Ms M Low for preparing the manuscript. 


\section{References}

1. Barré-Sinousi F, Chermann JC, Rey F, et al. Isolation of a T-lymphotropic retrovirus from a patient at risk for acquired immune deficiency syndrome (AIDS). Science 1983;220:86870.

2. Popovic M, Sarngadharan MG, Read E, Gallo RC. Detection, isolation, and continuous production of cytopathic retroviruses (HTLV-III) from patients with AIDS and pre-AIDS. Science 1984;224:497-500.

3. Gallo RC, Salahuddin SZ, Popovic M, et al. Frequent detection and isolation of cytopathic retroviruses (HTLV-III) from patients with AIDS and at risk for AIDS. Science 1984;224:500-3.

4. Schupbach J, Popovic M, Gilden RV, Gonda MA, Sarngadharan MG, Gallo RC. Serological analysis of a subgroup of human T-lymphotropic retroviruses (HTLV-III) associated with AIDS. Science 1984;224:503-5.

5. Sarngadharan MG, Popovic M, Bruch L, Schuphach J, Gallo RC. Antibodies reactive with human T-lymphotropic retrovirus (HTLV-III) in the serum of patients with AIDS. Science 1984;224:506-8.

6. Weiss R. Acquired immune deficiency syndrome: retroviruses linked with AIDS. Nature 1984;309:12-3.

7. Levy JA, Hoffman AD, Kramer SM, Landis JA, Shimabukuro JM, Oshiro LS. Isolation of lymphocytopathic retroviruses from San Francisco patients with AIDS. Science 1984; 225:840-2.

8. du Bois RM, Branthwaite MA, Mikhail JR, Batten JC. Primary Pneumocystis carinii and cytomegalovirus infections. Lancet 1981;ii:1339.
9. Griffiths PD, Kangro HO. A user's guide to the indirect solidphase radioimmunoassay for the detection of cytomegalovirus specific IgM antibodies. J Virol Methods 1984;8:271-82.

10. Groopman JE, Salahuddin SZ, Sarngadharan MG. Virologic studies in a case of transfusion-associated AIDS. NEnglJ Med 1984;311:1419-22.

11. Miller RA, Collier AC, Buchanan TM, Handsfield HH. Seroepidemiologic screening for antibodies to LAV-HTLV-III in Sri Lanka 1980-1982. N Engl J Med 1985;313:1352-3.

12. Carne CA, Weller IVD, Sutherland $S$, et al. Rising prevalence of human T-lymphotropic virus type III (HTLV-III) infection in homosexual men in London. Lancet 1985; i:1261-2.

13. Jaffe HW, Darrow WW, Echenberg DF, et al. The acquired immunodeficiency syndrome in a cohort of homosexual men: a six-year follow-up study. Ann Intern Med 1985;103:210-4.

14. Cheingsong-Popov R, Weiss RA, Dalgleish A, et al. Prevalence of antibody to human T-lymphotropic virus type III in AIDS and AIDS-risk patients in Britain. Lancet 1984;ii:477-80.

15. Mortimer PP, Jesson WJ, Vandervelde EM, Pereira MS. Prevalence of antibody to human T-lymphotropic virus type III by risk group and area, United Kingdom 1978-84. B Med J 1985;290:1176-8.

16. Drew WL, Mintz L, Miner RC, Sands M, Ketterer B. Prevalence of cytomegalovirus infection in homosexual men. $J$ Infect Dis 1984;143:188-92.

17. Pinching AJ, McManus TJ, Jeffries DJ, et al. Studies of cellular immunity in male homosexuals in London. Lancet 1983;ii:12630. 